\title{
The Welfare and Sectoral Adjustment Effects of Mega-Regional Trade Agreements on ASEAN Countries*
}

\author{
November 6, 2017 \\ Hiro Lee ${ }^{\dagger}$ \\ Professor, Osaka School of International Public Policy, Osaka University \\ Ken Itakura \\ Professor, Graduate School of Economics, Nagoya City University
}

Keywords: MRTA, RCEP, TPP, FTAAP, CGE model, ASEAN

JEL codes: F13, F14, F15, F17

Abstract: The U.S. withdrawal from the Trans-Pacific Partnership (TPP) has had an influence on the prospects of mega-regional trade agreements (MRTAs). In the Asian Pacific, negotiations for the Regional Comprehensive Economic Partnership (RCEP) might accelerate. In addition, ministers from the 11 other TPP signatories have confirmed their intention to proceed with the TPP without U.S. participation. Using a dynamic computable general equilibrium (CGE) model, we estimate welfare and sectoral output adjustment effects of alternative sequencings of MRTAs on ASEAN countries. Welfare gains for ASEAN countries under the scenario led by the RCEP, followed by RCEP + Taiwan and a Free Trade Area of the Asia-Pacific (FTAAP), are greater than or equal to those under the scenario led by TPP sans US, followed by an enlarged TPP and an FTAAP. When the two scenarios are assumed to develop at the same time, welfare gains of the RCEP and TPP-11 countries are found to be less than the sum of the gains under the first two scenarios. For a number of ASEAN countries, output expansion of textiles and apparel and/or electronic equipment is significant.

\footnotetext{
* Forthcoming in the Journal of Asian Economics. We have benefitted from the helpful comments of two anonymous reviewers, Michael G. Plummer, Anna Strutt, Fan Zhai, and other participants at the Conference on Trade, Industrialization and Structural Reforms in ASEAN, Ho Chi Minh City, January 9-10, 2017. We gratefully acknowledge financial support from the Japan Society for the Promotion of Science (JSPS), Grant Number JP16H03616.

$\dagger$ Corresponding author. Osaka School of International Public Policy, Osaka University, 1-31 Machikaneyama, Toyonaka, Osaka 560-0043, Japan. Email: hlee@,osipp.osaka-u.ac.jp.
} 


\section{Introduction}

Until the U.S. withdrawal from the Trans-Pacific Partnership (TPP) in January 2017, the Asia-Pacific region was moving toward consolidations of bilateral free trade agreements (FTAs). Combining smaller FTAs would enlarge the welfare gains from increased trade creation and mitigate the cost of different rules of origin associated with a large number of FTAs (e.g. Kawai and Wignaraja, 2009; Itakura and Lee, 2012). Negotiations for the Regional Comprehensive Economic Partnership (RCEP) among the ten ASEAN countries, Australia, China, India, Japan, Korea and New Zealand started in 2013 and might accelerate amid the U.S. withdrawal from the TPP. In addition, ministers from the 11 other TPP signatories have confirmed their intention to proceed with the TPP without U.S. participation. By implementing the TPP sans US or "TPP-11", the member countries will keep the option for a future U.S. participation (Schott, 2016; Solís, 2016). Furthermore, while it may still be a long way to realize a Free Trade Area of the AsiaPacific (FTAAP), APEC leaders agreed to consider the eventual realization of FTAAP at the APEC Summit in Lima, November 2016.

The objective of this paper is to estimate welfare and sectoral output adjustment effects of alternative sequencings of mega-regional trade agreements (MRTAs) on ASEAN countries using a dynamic computable general equilibrium (CGE) model. We offer four possible sequencings of MRTAs in the Asia-Pacific. The first is the implementation of the 16-member RCEP, followed by RCEP + Taiwan and an FTAAP. The second is the realization of 11-member TPP sans US, followed by an enlarged TPP and an FTAAP. The third is a more hypothetical scenario in which the implementation of the TPP including the United States as a member is considered for a comparison. Finally, a simultaneous development of the first and second sequencings is considered.

A number of studies have quantified the effects of plurilateral FTAs and/or MRTAs in the Asia-Pacific region using a CGE model (e.g., Cheong, 2013; Kawasaki, 2015; Lee et al., 2009; Li and Whalley, 2014; Petri et al., 2012, 2014; Petri and Plummer, 2016; World Bank, 2016). Using a dynamic CGE model, Lee et al. (2009) find that a reduction in administrative and technical barriers and a fall in the trade and transport margins have greater effects on economic welfare of member countries than tariff elimination. Cheong 
and Tongzon (2013) and Kawasaki (2015) show that real GDP gains will be larger under the RCEP than under the TPP. In both studies Singapore and Vietnam's income gains are relatively large, particularly under the RCEP. Malaysia's income gains are also large in Kawasaki's (2015) study. Li and Whalley (2014) demonstrate that China's participation in the TPP would significantly benefit China and moderately increase economic welfare of other TPP members.

Petri et al. (2012)'s study is the first to compare Trans-Pacific (or TPP) track and Asian track FTAs. They assume that a China-Japan-Korea FTA is implemented before an East Asian FTA and an FTAAP under the Asian track. They find that by far Vietnam is the largest beneficiary under both tracks. Several countries' welfare gains are found to be larger under the TPP track than under the Asian track. In a subsequent study, Petri et al. (2014) assume that the TPP will expand from 12 to 17 members to include China, Indonesia, Korea, the Philippines and Thailand. ${ }^{1}$ Using more recent data and estimates on nontariff barriers (NTBs), Petri and Plummer (2016) updates Petri et al. (2012)'s study. Economic welfare of the 12 TPP members, expressed as percent change from the baseline in 2030 , ranges from $0.5 \%$ in the United States to $8.1 \%$ in Vietnam. World Bank's (2016) results are similar, as smaller and more open member countries (e.g. Vietnam and Malaysia) are expected to attain relatively large welfare gains.

An overview of the model and data is given in the next section, followed by descriptions of the baseline and policy scenarios in Section 3. In Section 4 assessments of welfare and sectoral output adjustment effects are offered. Concluding remarks are provided in the final section.

\section{Analytical Framework and Data}

\subsection{Overview of the Dynamic GTAP Model}

The numerical simulations undertaken for this study are derived from the dynamic GTAP model, described in detail by Ianchovichina and McDougall (2012). This model

\footnotetext{
${ }^{1}$ It might be more reasonable to assume, however, that China's participation in the TPP comes after the other countries' accession because it is expected to take longer to meet the high standards of the TPP, including competition policy, government procurement and intellectual property rights.
} 
extends the comparative static framework of the standard GTAP model developed by Hertel (1997) to the dynamic framework by incorporating international capital mobility and capital accumulation. The dynamic GTAP model allows international capital mobility and capital accumulation, while it preserves all the features of the standard GTAP, such as constant returns to production technology, perfectly competitive markets, and product differentiation by countries of origin, in keeping with the so-called Armington assumption. $^{2}$ At the same time, it enhances the investment theory by incorporating international capital mobility and ownership. In this way it captures important FTA effects on investment and wealth that are missed by a static model.

In the dynamic GTAP model, each of the regions is endowed with fixed physical capital stock owned by domestic firms. The physical capital is accumulated over time with new investment. This dynamics are driven by net investment, which is sourced from regional households' savings. The savings in one region are invested directly in domestic firms and indirectly in foreign firms, which are in turn reinvested in all regions. The dynamics arising from positive savings in one region is related to the dynamics from the net investment in other regions. Overall, at the global level, it must hold that all the savings across regions are completely invested in home and overseas markets.

In the short run, an equalization of the rates of return seems unrealistic, and there exist well-known empirical observations for "home bias" in savings and investment. These observations suggest that capital is not perfectly mobile, causing some divergence in the rates of return across regions. The dynamic GTAP model allows inter-regional differences in the rates of return in the short run, which will be eventually equalized in the very long run. It is assumed that differences in the rates of return are attributed to the errors in investors' expectations about the future rates of return. During the process, these errors are gradually adjusted to the actual rate of return as time elapses, and eventually they are eliminated and a unified rate of return across regions can be attained. Income accruing

\footnotetext{
2 See Armington (1969). The model uses a nested CES structure, where at the top nested level, each agent chooses to allocate aggregate demand between domestically produced goods and an aggregate import bundle, while minimizing the overall cost of the aggregate demand bundle. At the second level, aggregate import demand is allocated across different trading partners, again using a CES specification, wherein the aggregate costs of imports are minimized.
} 
from the ownership of the foreign and domestic assets can then be appropriately incorporated into total regional income.

Participating in an FTA could lead to more investment from abroad. Trade liberalization often makes prices of goods in a participating country lower due to removal of tariffs, creating an increase in demand for the goods. Responding to the increased demand, production of the goods expands in the member country. The expansion of production is attained by using more intermediate inputs, labor, capital, and other primary factor inputs. These increased demands for production inputs raise the corresponding prices, wage rates, and rental rates. Higher rental rates are translated into higher rates of return, attracting more investment from both home and foreign countries.

\subsection{Data, aggregation and initial tariffs}

In this study we employ the GTAP database version 9, which has a 2011 base year and distinguishes 140 countries/regions and 57 sectors (Aguiar et al., 2016). For the purposes of the present study, the data has been aggregated to 23 countries/regions and 29 sectors, as shown in Table 1. Foreign income data are obtained from the International Monetary Fund (IMF)'s Balance of Payments Statistics, which are used to track international capital mobility and foreign wealth. The values of key parameters, such as demand, supply and CES substitution elasticities, are based upon previous empirical estimates. The model calibration primarily consists of calculating share and shift parameters to fit the model specifications to the observed data, so as to be able to reproduce a solution for the base year.

The sectoral tariff rates on 22 commodities and tariff equivalents of nontariff barriers (NTBs) on seven services sectors are summarized in Table 2. There are striking differences in the tariff structures across the countries/regions. Singapore is duty free with the exception of alcohol and tobacco. Brunei's tariff rates are low, except on other food products, machinery and motor vehicles. Among the ASEAN countries, Thailand's tariff rates are comparatively high, exceeding $20 \%$ on five commodities: other grains, sugar, meats, apparel and motor vehicles. The tariff rates on agricultural and food products are relatively high in several other ASEAN and non-ASEAN countries/regions, such as rice in 
Japan, Malaysia, the Philippines and Russia, other grains and other crops in Korea, sugar in China, Japan, India and the Philippines, meats in Japan, Korea, Canada, the Philippines, Vietnam and the rest of ASEAN, and dairy products in Canada, Japan, Korea and India. In manufacturing the tariff rates on apparel are relatively high in Vietnam, the rest of ASEAN, Japan, India, the United States, Canada, Mexico, Peru and Russia. The tariff rate on motor vehicles exceeds $15 \%$ in Malaysia, Vietnam, the rest of ASEAN, China, India, Australia and Russia.

\section{Table 1. Regional and sectoral aggregation}

A. Regional aggregation

\begin{tabular}{rll}
\hline & Country/region & Corresponding economies/regions in the GTAP 9 database \\
\hline 1 & Singapore & Singapore \\
2 & Brunei & Brunei Darussalam \\
3 & Indonesia & Indonesia \\
4 & Malaysia & Malaysia \\
5 & Philippines & Philippines \\
6 & Thailand & Thailand \\
7 & Vietnam & Vietnam \\
8 & Rest of ASEAN & Cambodia, Laos, rest of Southeast Asia \\
9 & Japan & Japan \\
10 & China & China, Hong Kong \\
11 & Korea & Korea \\
12 & Taiwan & Taiwan \\
13 & India & India \\
14 & Australia & Australia \\
15 & New Zealand & New Zealand \\
16 & United States & United States \\
17 & Canada & Canada \\
18 & Mexico & Mexico \\
19 & Chile & Chile \\
20 & Peru & Peru \\
21 & Russia & Russian Federation \\
22 & EU-28 & Austria, Belgium, Bulgaria, Croatia, Cyprus, Czech Republic, Denmark, \\
& & Estonia, Finland, France, Germany, Greece, Hungary, Ireland, Italy, \\
& Latvia, Lithuania, Luxembourg, Malta, Netherlands, Poland, Portugal, \\
23 & Rest of world & Romania, Slovakia, Slovenia, Spain, Sweden, United Kingdom \\
\hline & & All the other economies/regions \\
\hline & &
\end{tabular}




\section{Table 1 (continued)}

B. Sectoral aggregation

\begin{tabular}{rll}
\hline & Sector & Corresponding commodities/sectors in the GTAP 9 database \\
\hline 1 & Rice & Paddy rice, processed rice \\
2 & Other grains & Wheat, cereal grains nec \\
3 & Sugar & Sugar, sugar cane and sugar beet \\
4 & Other crops & Vegetables and fruits, oil seeds, plant-based fibers, crops nec \\
5 & Livestock & Cattle, sheep and goats, animal products nec, raw milk, wool \\
6 & Meats & Cattle, sheep, goat, and horse meat products, meat products nec \\
7 & Dairy products & Dairy products \\
8 & Other food products & Vegetable oils, food products nec, beverages and tobacco products \\
9 & Fossil fuels & Coal, oil, gas \\
10 & Natural resources & Forestry, fishing, minerals nec \\
11 & Textiles & Textiles \\
12 & Apparel & Wearing apparel, leather products \\
13 & Petroleum products & Petroleum, coal products \\
14 & Chemical products & Chemical, rubber, plastic products \\
15 & Steel & Iron and steel \\
16 & Nonferrous metal & Nonferrous metal \\
17 & Metal products & Fabricated metal products \\
18 & Machinery & Machinery and equipment \\
19 & Electronic equipment & Electronic equipment \\
20 & Motor vehicles & Motor vehicles and parts \\
21 & Other transport equip. & Transport equipment nec \\
22 & Other manufactures & Wood products; paper products, publishing, mineral products nec, \\
23 & Construction and utilities & manufactures nec \\
24 & Trade & Construction, electricity, gas manufacture and distribution, water \\
25 & Transport & Trade \\
26 & Communication & Sea transport, air transport, other transport \\
27 & Financial services & Communication \\
28 & Other private services & Insurance, financial services nec \\
29 & Government services & Business services, recreation and other services \\
\hline & & Public administration and defense, education, health services \\
\hline & &
\end{tabular}

Source: GTAP database, version 9.

Note: nec $=$ not elsewhere classified. 
Table 2. Tariff rates on merchandise imports and tariff equivalents of nontariff barriers on services, 2011 (\%)

\begin{tabular}{|c|c|c|c|c|c|c|c|c|c|c|c|c|c|}
\hline & Sector & Singapore & Brunei & Indonesia & Malaysia & Philippines & Thailand & Vietnam & $\begin{array}{l}\text { Rest of } \\
\text { ASEAN }\end{array}$ & China & Japan & Korea & Taiwan \\
\hline 1 & Rice & 0.0 & 0.0 & 7.1 & 39.9 & 40.1 & 18.7 & 10.8 & 5.5 & 0.6 & 240.6 & 4.9 & 0.6 \\
\hline 2 & Other grains & 0.0 & 0.0 & 4.8 & 0.0 & 2.3 & 26.4 & 2.7 & 1.0 & 1.2 & 12.1 & 250.3 & 1.7 \\
\hline 3 & Sugar & 0.0 & 0.0 & 10.1 & 0.0 & 24.0 & 43.4 & 6.1 & 2.6 & 47.5 & 26.1 & 3.1 & 7.5 \\
\hline 4 & Other crops & 0.0 & 0.4 & 1.8 & 13.4 & 3.1 & 14.3 & 4.3 & 9.6 & 3.0 & 5.1 & 130.7 & 6.9 \\
\hline 5 & Livestock & 0.0 & 0.0 & 3.0 & 0.1 & 3.2 & 9.0 & 1.5 & 6.8 & 14.9 & 4.9 & 6.0 & 1.4 \\
\hline 6 & Meats & 0.0 & 0.0 & 4.8 & 0.2 & 14.1 & 25.2 & 14.2 & 26.0 & 6.0 & 37.4 & 29.1 & 9.9 \\
\hline 7 & Dairy products & 0.0 & 0.0 & 4.7 & 1.1 & 1.0 & 10.5 & 4.7 & 8.4 & 5.7 & 53.5 & 57.3 & 8.9 \\
\hline 8 & Other food products & 0.4 & 17.0 & 6.9 & 8.2 & 2.8 & 11.9 & 11.1 & 9.6 & 7.0 & 8.5 & 30.7 & 12.8 \\
\hline 9 & Fossil fuels & 0.0 & 0.0 & 0.0 & 1.8 & 0.0 & 0.0 & 1.2 & 1.0 & 0.2 & 0.0 & 2.5 & 0.0 \\
\hline 10 & Natural resources & 0.0 & 0.1 & 0.9 & 0.1 & 2.0 & 2.0 & 3.3 & 4.3 & 0.1 & 0.2 & 0.5 & 1.1 \\
\hline 11 & Textiles & 0.0 & 1.2 & 2.0 & 7.3 & 2.1 & 6.4 & 10.0 & 8.2 & 4.1 & 5.4 & 7.8 & 6.2 \\
\hline 12 & Apparel & 0.0 & 2.8 & 5.2 & 8.4 & 3.5 & 21.1 & 14.3 & 12.0 & 4.0 & 11.3 & 8.8 & 8.1 \\
\hline 13 & Petroleum products & 0.0 & 0.8 & 1.5 & 0.5 & 0.1 & 2.6 & 8.2 & 12.1 & 3.4 & 0.7 & 3.7 & 1.7 \\
\hline 14 & Chemical products & 0.0 & 1.5 & 3.9 & 4.9 & 2.2 & 7.1 & 3.3 & 4.5 & 4.7 & 0.8 & 4.8 & 1.9 \\
\hline 15 & Steel & 0.0 & 0.0 & 3.3 & 18.7 & 0.8 & 3.9 & 1.7 & 2.2 & 3.2 & 0.4 & 0.4 & 0.1 \\
\hline 16 & Nonferrous metal & 0.0 & 0.0 & 2.1 & 3.2 & 0.5 & 0.4 & 1.0 & 2.9 & 0.8 & 0.4 & 2.5 & 0.5 \\
\hline 17 & Metal products & 0.0 & 0.0 & 4.5 & 9.9 & 2.6 & 10.9 & 8.1 & 5.0 & 7.9 & 0.4 & 4.9 & 4.7 \\
\hline 18 & Machinery & 0.0 & 11.6 & 3.9 & 2.3 & 1.0 & 6.2 & 3.5 & 5.5 & 5.5 & 0.0 & 5.5 & 1.9 \\
\hline 19 & Electronic equipment & 0.0 & 4.9 & 0.2 & 0.1 & 0.6 & 2.3 & 1.5 & 9.7 & 1.5 & 0.0 & 0.5 & 0.2 \\
\hline 20 & Motor vehicles & 0.0 & 18.8 & 8.6 & 15.0 & 8.5 & 28.6 & 20.2 & 17.8 & 17.5 & 0.0 & 7.0 & 12.5 \\
\hline 21 & Other trans port equip. & 0.0 & 0.2 & 1.4 & 1.2 & 4.5 & 5.1 & 10.3 & 5.7 & 2.8 & 0.0 & 1.3 & 1.5 \\
\hline 22 & Other manufactures & 0.0 & 2.3 & 2.8 & 7.5 & 2.2 & 6.7 & 10.7 & 7.4 & 3.2 & 1.0 & 4.8 & 2.8 \\
\hline 23 & Construction and utilities & 0.0 & 20.6 & 64.4 & 17.4 & 52.6 & 44.9 & 53.7 & 20.6 & 25.2 & 5.0 & 13.0 & 10.8 \\
\hline 24 & Trade & 1.3 & 32.5 & 98.5 & 36.0 & 80.2 & 63.5 & 82.7 & 32.5 & 109.6 & 22.7 & 33.0 & 28.8 \\
\hline 25 & Transport & 1.3 & 16.6 & 84.2 & 27.6 & 68.0 & 53.0 & 69.7 & 16.6 & 52.4 & 15.8 & 25.1 & 21.4 \\
\hline 26 & Communication & 1.3 & 32.8 & 88.4 & 30.0 & 71.5 & 56.1 & 73.5 & 32.8 & 48.1 & 17.8 & 27.4 & 23.6 \\
\hline 27 & Financial services & 1.5 & 20.0 & 92.5 & 30.2 & 72.6 & 58.1 & 74.7 & 20.0 & 83.3 & 17.1 & 30.4 & 27.5 \\
\hline 28 & Other private services & 1.5 & 7.3 & 91.1 & 29.8 & 70.8 & 54.9 & 73.7 & 7.3 & 81.2 & 16.6 & 29.2 & 26.7 \\
\hline 29 & Government services & 2.8 & 24.1 & 97.8 & 36.5 & 76.9 & 61.5 & 84.2 & 24.1 & 84.1 & 25.9 & 34.3 & 29.1 \\
\hline
\end{tabular}


Table 2 (continued)

\begin{tabular}{|c|c|c|c|c|c|c|c|c|c|c|c|c|}
\hline & Sector & India & Australia & $\begin{array}{c}\text { New } \\
\text { Zealand }\end{array}$ & $\begin{array}{l}\text { United } \\
\text { States }\end{array}$ & Canada & Mexico & Chile & Peru & Russia & EU-28 & $\begin{array}{c}\text { Rest of } \\
\text { world }\end{array}$ \\
\hline 1 & Rice & 11.1 & 0.0 & 0.0 & 0.8 & 0.0 & 0.0 & 4.8 & 0.0 & 108.3 & 5.7 & 9.0 \\
\hline 2 & Other grains & 4.2 & 0.0 & 0.0 & 0.0 & 0.0 & 0.6 & 1.8 & 2.9 & 3.9 & 1.5 & 8.0 \\
\hline 3 & Sugar & 58.3 & 0.0 & 0.0 & 6.0 & 0.2 & 18.4 & 3.5 & 0.0 & 20.3 & 12.3 & 9.9 \\
\hline 4 & Other crops & 23.1 & 0.4 & 0.0 & 0.6 & 0.2 & 2.1 & 0.6 & 3.6 & 8.3 & 1.0 & 8.1 \\
\hline 5 & Livestock & 5.8 & 0.1 & 0.0 & 0.3 & 10.4 & 0.3 & 0.3 & 1.8 & 7.2 & 0.5 & 9.2 \\
\hline 6 & Meats & 17.3 & 0.1 & 1.7 & 1.7 & 33.8 & 1.1 & 3.8 & 3.2 & 31.2 & 5.4 & 18.8 \\
\hline 7 & Dairy products & 41.0 & 2.2 & 2.5 & 10.3 & 191.3 & 8.3 & 1.1 & 0.0 & 12.7 & 1.1 & 11.3 \\
\hline 8 & Other food products & 58.7 & 1.3 & 1.0 & 1.7 & 8.7 & 3.9 & 1.1 & 0.8 & 12.9 & 1.6 & 13.3 \\
\hline 9 & Fossil fuels & 0.6 & 0.0 & 0.0 & 0.0 & 0.0 & 0.0 & 1.4 & 0.0 & 1.2 & 0.0 & 0.3 \\
\hline 10 & Natural resources & 5.8 & 0.0 & 0.0 & 0.0 & 0.0 & 1.2 & 0.1 & 0.3 & 5.2 & 0.1 & 1.5 \\
\hline 11 & Textiles & 13.0 & 5.5 & 4.7 & 6.9 & 6.3 & 5.7 & 3.2 & 7.6 & 14.3 & 2.6 & 9.9 \\
\hline 12 & Apparel & 10.2 & 6.7 & 8.6 & 10.9 & 10.7 & 16.0 & 3.3 & 10.4 & 17.7 & 4.2 & 12.3 \\
\hline 13 & Petroleum products & 5.4 & 0.0 & 0.2 & 0.8 & 0.1 & 0.2 & 0.1 & 0.0 & 2.4 & 0.3 & 3.6 \\
\hline 14 & Chemical products & 7.5 & 1.5 & 1.2 & 1.2 & 0.4 & 1.0 & 0.7 & 1.4 & 8.5 & 0.5 & 4.3 \\
\hline 15 & Steel & 5.3 & 3.3 & 1.8 & 0.2 & 0.0 & 1.6 & 1.5 & 0.0 & 5.4 & 0.0 & 4.4 \\
\hline 16 & Nonferrous metal & 9.3 & 0.4 & 0.7 & 0.5 & 0.0 & 1.1 & 1.2 & 0.0 & 4.8 & 0.4 & 1.0 \\
\hline 17 & Metal products & 9.5 & 3.6 & 2.4 & 1.6 & 0.6 & 1.5 & 0.8 & 0.9 & 10.5 & 0.5 & 7.4 \\
\hline 18 & Machinery & 7.5 & 1.9 & 2.1 & 0.8 & 0.2 & 1.6 & 0.4 & 0.6 & 3.2 & 0.4 & 5.1 \\
\hline 19 & Electronic equipment & 1.8 & 0.5 & 0.4 & 0.2 & 0.1 & 0.7 & 0.2 & 1.4 & 3.9 & 0.5 & 3.5 \\
\hline 20 & Motor vehicles & 20.3 & 18.2 & 5.6 & 0.6 & 1.0 & 2.4 & 0.7 & 2.3 & 17.0 & 0.6 & 8.7 \\
\hline 21 & Other trans port equip. & 7.9 & 1.6 & 0.5 & 0.5 & 0.6 & 3.8 & 0.2 & 2.7 & 5.4 & 0.6 & 6.5 \\
\hline 22 & Other manufactures & 9.1 & 2.7 & 1.4 & 0.9 & 0.7 & 2.5 & 0.9 & 2.7 & 11.0 & 0.4 & 6.0 \\
\hline 23 & Construction and utilities & 109.7 & 4.3 & 1.0 & 2.3 & 9.2 & 40.8 & 25.8 & 27.2 & 52.9 & 5.6 & 26.7 \\
\hline 24 & Trade & 153.3 & 18.2 & 8.2 & 6.8 & 20.7 & 61.8 & 33.8 & 51.0 & 73.5 & 12.0 & 48.2 \\
\hline 25 & Transport & 133.3 & 11.4 & 5.1 & 6.8 & 14.0 & 51.2 & 26.0 & 41.7 & 61.9 & 8.9 & 37.1 \\
\hline 26 & Communication & 139.2 & 13.4 & 4.3 & 6.8 & 15.9 & 54.3 & 28.3 & 44.4 & 65.3 & 9.3 & 36.6 \\
\hline 27 & Financial services & 139.5 & 13.5 & 4.3 & 7.8 & 19.8 & 57.6 & 27.5 & 46.4 & 65.9 & 8.7 & 43.3 \\
\hline 28 & Other private services & 137.1 & 13.5 & 3.7 & 7.8 & 19.2 & 58.2 & 26.5 & 43.8 & 65.1 & 9.7 & 40.5 \\
\hline 29 & Government services & 154.8 & 23.5 & 10.2 & 6.3 & 17.5 & 60.3 & 33.0 & 47.3 & 69.7 & 14.2 & 45.8 \\
\hline
\end{tabular}

Sources: Sectors 1-22 GTAP database, version 9. Sectors 23-29: averages of the gravity-model estimates of Wang et al. (2009) and the values employed by the Michigan Model of World Production and Trade. 
Ad valorem tariff equivalents of NTBs in services sectors are computed as unweighted averages of the gravity-model estimates of Wang et al. (2009) and the values employed by the Michigan Model of World Production and Trade (e.g. Brown, Kiyota and Stern, 2010). There are even greater variations in tariff equivalents of NTBs in services than in commodities. Among the ASEAN countries they are comparatively high in Indonesia, the Philippines, Thailand and Vietnam.

\section{The Baseline and Policy Scenarios}

\subsection{The Baseline Scenario}

In order to evaluate the effects of region-wide FTAs in the Asia-Pacific, the baseline scenario is first established, showing the path of each of the 23 economies/regions over the period 2011-2035. The baseline contains information on macroeconomic variables as well as expected policy changes. The macroeconomic variables in the baseline include projections for real GDP, gross investment, capital stocks, population, and total labor. Real GDP projections and gross investment were obtained from International Monetary Fund (2016). Projections for population were taken from the United Nations (2015), while those for labor were based on the working-age population (15-64 years old).

The projections for population, investment, and labor obtained for over 150 countries were aggregated, and the growth rates were calculated to obtain the macroeconomic shocks describing the baseline. Changes in the capital stocks were not imposed exogenously, but were determined endogenously as the accumulation of projected investment. Any changes in real GDP not explained by the changes in endowments are attributed to technological change.

In addition, policy projections are also introduced into the baseline. Trade accords included in the baseline are those which are already agreed among the member countries, including the ASEAN-China, ASEAN-Korea, ASEAN-Japan, ASEAN-Australia-New Zealand, ASEAN-India, EU-Korea, Korea-US, Australia-Japan, Australia-Korea, Australia-China and China-Korea FTAs. It is assumed that tariffs are cut by $80 \%$ among the member countries of the FTAs that are being implemented. Productivity is assumed to increase by 1 percent per year in every sector in all countries/regions. 


\subsection{Policy Scenarios}

Welfare and sectoral output effects of MRTAs and their implications for ASEAN countries are to be evaluated in this study. The following four scenarios are designed and summarized in Table 3.

Table 3. Policy scenarios

\begin{tabular}{|c|c|c|c|c|c|}
\hline & 2019-2023 & 2024-2027 & 2028 & 2029-2033 & $2034-35$ \\
\hline \multirow{3}{*}{$\begin{array}{l}\text { Scenario 1: } \\
\text { Asian track }\end{array}$} & \multicolumn{3}{|c|}{ RCEP (ASEAN+6 FTA) (2019-2028) } & & \\
\hline & & \multicolumn{3}{|c|}{ RCEP + Taiwan (2024-2033) } & \\
\hline & & & \multicolumn{3}{|c|}{ FTAAP (2028-2035) (80\% implemented) } \\
\hline \multirow{3}{*}{$\begin{array}{l}\text { Scenario 2: } \\
\text { Trans-Pacific } \\
\text { track 1 }\end{array}$} & \multicolumn{3}{|c|}{ ТРP-11 (2019-2028) } & & \\
\hline & & \multicolumn{3}{|c|}{ ТРP-16 (2024-2033) } & \\
\hline & & & \multicolumn{3}{|c|}{ FTAAP (2028-2035) (80\% implemented) } \\
\hline \multirow{3}{*}{$\begin{array}{l}\text { Scenario 3: } \\
\text { Trans-Pacific } \\
\text { track } 2\end{array}$} & \multicolumn{3}{|c|}{ TPP-12 (2019-2028) } & & \\
\hline & & \multicolumn{3}{|c|}{ ТРP-16 (2024-2033) } & \\
\hline & & & \multicolumn{3}{|c|}{ FTAAP (2028-2035) (80\% implemented) } \\
\hline \multirow{5}{*}{$\begin{array}{l}\text { Scenario 4: } \\
\text { Two tracks }\end{array}$} & \multicolumn{3}{|c|}{ RCEP (ASEAN+6 FTA) (2019-2028) } & & \\
\hline & \multicolumn{3}{|c|}{ TPP-11 (2019-2028) } & & \\
\hline & & \multicolumn{3}{|c|}{ RCEP + Taiwan (2024-2033) } & \\
\hline & & \multicolumn{3}{|c|}{ ТРP-16 (2024-2033) } & \\
\hline & & & \multicolumn{3}{|c|}{ FTAAP (2028-2035) (80\% implemented) } \\
\hline
\end{tabular}

Note: RCEP: 10 ASEAN countries, Australia, China, India, Japan, Korea and New Zealand. TPP-11 (TPP sans US): Australia, Brunei, Canada, Chile, Japan, Malaysia, Mexico, New Zealand, Peru, Singapore and Vietnam. TPP-12: TPP-11 plus the United States. TPP-16: TPP-12 plus Korea, Indonesia, the Philippines and Thailand. FTAAP: 10 ASEAN countries, Australia, Canada, Chile, China, India, Japan, Korea, Mexico, New Zealand, Peru, Russia, Taiwan and the United States.

Scenario 1 (Asian track): RCEP over the period 2019-2028, RCEP + Taiwan from 20242033 and FTAAP from 2028-2035.

Scenario 2 (Trans-Pacific track 1): TPP-11 (TPP sans US) from 2019-2028, TPP-16 from 2024-2033, and FTAAP from 2028-2035. 
Scenario 3 (Trans-Pacific track 2): Same as Scenario 2, except that the United States is assumed to reverse its decision to withdraw from the TPP.

Scenario 4 (Two tracks): RCEP and TPP-11 over the period 2019-2028, RCEP + Taiwan and TPP-16 from 2024-2033 and FTAAP from 2028-2035.

In all three scenarios, $80 \%$ of FTAAP is assumed to be implemented in 2035 . In Scenario 1, we assume that 10 ASEAN countries, Australia, China, India, Japan, Korea and New Zealand will reach final agreement on the RCEP by 2018 and will implement the agreement over the 2019-2028 period. The RCEP is expected to be open to new members, and we assume that Taiwan will become a new member in 2024. Although it is uncertain as to when an FTAAP will be realized, it is assumed that the FTAAP consisting of the APEC member countries, Brunei, Cambodia, India and Laos will come into effect in $2028 .^{3}$

In Scenario 2, we assume that TPP signatories other than the United States will agree on a similar deal to that signed in February 2016 and implement it over the 2019-2028 period. The 11 members will keep the option for a future participation by the United States and other countries. We assume that the U.S. and four other countries previously expressed an interested in joining the TPP - Korea, Indonesia, the Philippines and Thailand - will become new members in 2024 and completes the implementation in 2033. This is followed by FTAAP, which will enter into force in 2028.

Scenarios 3 is a hypothetical scenario in which the 12 TPP signatories including the United States will implement the TPP over the 2019-2028 period, followed by an enlargement in 2024 and a creation of the FTAAP in 2028 as in Scenario 2. This scenario is added to capture the differences in the welfare and sectoral effects between the U.S. participation from the beginning of the TPP implementation and a delay in its participation.

In Scenario 4, the Asian track and the first Trans-Pacific track are assumed to develop at the same time. The RCEP and TPP-11 will be implemented over the 2019-2028 period, followed by RCEP + Taiwan and TPP-16 from 2024-2033 and FTAAP from 2028-2035.

\footnotetext{
${ }^{3}$ Cambodia, India, Laos and Myanmar are not APEC members. However, since they are RCEP members, it would be more natural to assume that they will become members of the envisioned FTAAP.
} 
In all MRTAs it is assumed that the tariff rates on commodities other than rice, other grains, sugar, meats and dairy products decline linearly to zero and tariff equivalents of NTBs in services are reduced by 20 percent during the periods in consideration among the member countries. We assume that the tariff rates on five agricultural products will be reduced by 2 percent for rice, 50 percent for other grains (wheat, feed grains and other grains), 5 percent for sugar, 75 percent for meats, and 5 percent for dairy products, which are rough approximations of what were agreed during the TPP negotiations. ${ }^{4}$ In addition to reductions in tariffs and NTBs, time cost of trade - e.g. shipping delays arising from regulatory procedures and inadequate infrastructure - is assumed to fall by 20 percent among them. ${ }^{5}$

We also assume that productivity in agricultural and manufacturing sectors will increase gradually from 1 percent a year (baseline) to 1.1 percent a year over a 10 -year period during which the country becomes a member of an MRTA. 6 Previous studies have shown that import liberalization results in an increase in productivity through greater competition in liberalized sectors, larger imports of technology-intensive intermediate and capital goods, and increasing the quality and variety of intermediate inputs available to domestic producers. Trefler (2004) finds that the Canada-U.S. FTA resulted in large increases in labor productivity in industries with steep tariff cuts, whereas Lileeva (2008) finds that Canada's tariff cuts raised industry-level productivity by increasing the market shares of highly productive plants. Using a model with firm heterogeneity, Chen et al. (2009) show that trade openness exerts a positive effect on productivity and a negative effect on markups in the short run. Using highly disaggregated U.S. data, Amiti and Khandelwal (2013) exhibit a significant and positive relationship between import tariffs and quality upgrading for products close to the world quality frontier. Halpern et al. (2015) find that imports have a significant and large effect on firm productivity and that one-

\footnotetext{
${ }^{4}$ During the TPP negotiations, the minimum access quota or tariff-rate quota was agreed on rice, wheat and sugar, whereas the tariff rates would be reduced on beef, pork and some dairy products.

${ }^{5}$ For a detailed analysis of time cost of trade, see Hummels and Schaur (2013) and Minor (2013).

${ }^{6}$ For example, under Scenario 1 productivity in sectors 1-22 is assumed to increase from $1 \%$ a year in 2019 to $1.1 \%$ a year in 2029 for RCEP countries, from 1\% a year in 2024 to $1.1 \%$ a year in 2034 for Taiwan, and from $1 \%$ a year in 2028 to $1.07 \%$ a year in 2035 for the rest of FTAAP countries (i.e. Canada, Chile, Mexico, Peru, Russia and the United States).
} 
quarter of the productivity growth in Hungary during 1993-2002 was caused by imported inputs. Ahn et al. (2016) suggest that removal of remaining tariffs could increase aggregate productivity of developed countries by around 1 percent on average.

Two caveats should be borne in mind when interpreting the results presented in the next section. First, reductions of barriers on foreign direct investment (FDI) among the member countries is not considered because it requires data on FDI flows by source and host countries and industry, which are not published. For example, UNCTAD (2017) provides FDI data by source and host countries, but not by industry. A challenging extension of the study would be to endogenize FDI flows to consider attraction of these flows to developing member countries, which is expected to produce additional welfare gains.

Second, we do not measure the quality of FTAs/MRTAs, which affects the magnitudes of welfare gains of member countries. The quality of the TPP is considered to be one of the highest, if not the highest, among all FTAs, since it has an extremely high coverage of tariff elimination and covers investment, intellectual property, government procurement, competition policy, environment, labor (e.g. protection of workers' rights) and other WTOplus commitments. The quality of the RCEP is expected to be lower because the depth of coverage of goods and services is likely to shallower than the TPP. In addition, RCEP negotiations to date have not covered issues on environment or labor, and the extent of coverage on other issues is expected fall short of that of the TPP. However, since the RCEP is currently under negotiation, several assumptions would have to be made to assess its quality. Moreover, there is a need to develop a framework to measure the quality of FTAs. These issues are left for future research.

\section{Empirical Findings}

\subsection{Welfare Effects}

Economic welfare is largely determined by four factors: (1) allocative efficiency, (2) the terms of trade, (3) the contribution to equivalent variation (EV) of change in the price of capital investment goods, and (4) the contribution to EV of change in equity owned by a region. The fourth factor is determined by the change in equity income from ownership of 
capital endowments, and it can be further decomposed into three parts: a change in the domestic capital stock, a change in household income earned on capital abroad, and a change in the domestic capital owned by foreigners.

With respect to these four factors, the direction of a welfare change may be summarized as follows. The allocative efficiency effect is generally positive for members of MRTAs. This effect is particularly large for a country with high average initial tariffs. Theoretically, it might become negative when the extent of trade diversion is considerably large in FTAs with relatively low intraregional trade. The terms-of-trade effect is usually positive for the members with low average initial tariffs and negative for those with high initial tariffs. Previous studies (e.g. Brown, 1987; Balistreri and Markusen, 2009) have shown that monopoly power implicit in national product differentiation is the source of strong terms-of-trade effects resulting from tariff changes in models that incorporate the Armington assumption. An increase in the price of capital investment goods generally raises welfare. A welfare change resulting from a change in the equity holdings is positive if the sum of the region's foreign income receipts and an increase in the domestic capital stock is greater than the foreign income payment, and vice versa.

The welfare results of the four policy scenarios, as changes in equivalent variations relative to the baseline for the years 2022, 2028 and 2034, are summarized in Table 4. Panel A of the table gives absolute changes in billions of US dollars in 2011 prices, whereas panel B provides percent changes. Under Scenario 1, economic welfare of the RCEP members increases during 2022-2034, whereas that of the envisaged FTAAP members increases in 2034. The welfare gains for the ASEAN countries in 2034, compared with the baseline scenario in the same year, range from $\$ 2.1$ billion (Brunei) to $\$ 51.7$ billion (Indonesia) in absolute values. In terms of percent changes from the baseline in the same year, they range from 1.6\% (Brunei) to 3.7\% (Singapore and Thailand). While the terms of trade of countries with zero or low initial tariff rates (e.g. Singapore and Australia) improve, those of countries with high initial tariff rates (e.g. Thailand, Vietnam and the rest of ASEAN) deteriorate, often significantly reducing the welfare gains. For example, whereas real GDP gains for Thailand and Vietnam in 2034 are $7.1 \%$ and $6.4 \%$, 
Table 4. The welfare effects of mega-regional trade agreements: Changes in equivalent variations relative to the baseline

A. Absolute changes (US\$ billion in 2011 prices)

\begin{tabular}{|c|c|c|c|c|c|c|c|c|c|c|c|c|}
\hline & \multicolumn{3}{|c|}{$\begin{array}{c}\text { Scenario } 1 \\
\text { (Asian track) }\end{array}$} & \multicolumn{3}{|c|}{$\begin{array}{c}\text { Scenario } 2 \\
(\text { Trans-Pacific track } 1)\end{array}$} & \multicolumn{3}{|c|}{$\begin{array}{c}\text { Scenario } 3 \\
(\text { Trans-Pacific track 2) }\end{array}$} & \multicolumn{3}{|c|}{$\begin{array}{c}\text { Scenario } 4 \\
\text { (Two tracks) }\end{array}$} \\
\hline & 2022 & 2028 & 2034 & 2022 & 2028 & 2034 & 2022 & 2028 & 2034 & 2022 & 2028 & 2034 \\
\hline Singapore & 1.4 & 5.8 & 8.4 & 0.6 & 4.1 & 8.5 & 0.7 & 4.1 & 8.5 & 1.6 & 6.5 & 8.8 \\
\hline Brunei & 0.1 & 0.5 & 2.1 & 0.0 & 0.3 & 1.1 & 0.0 & 0.2 & 0.9 & 0.1 & 0.5 & 2.0 \\
\hline Indonesia & 3.0 & 20.8 & 51.7 & -0.2 & 5.8 & 32.1 & -0.4 & 4.8 & 31.1 & 2.9 & 23.3 & 56.5 \\
\hline Malaysia & 0.9 & 6.1 & 14.8 & 0.8 & 5.2 & 14.1 & 1.0 & 5.4 & 14.2 & 1.1 & 7.3 & 15.9 \\
\hline Philippines & 0.8 & 3.7 & 10.7 & 0.0 & 1.3 & 7.4 & -0.1 & 1.2 & 7.3 & 0.8 & 4.3 & 12.3 \\
\hline Thailand & 1.6 & 6.7 & 13.5 & -0.1 & 3.5 & 12.0 & -0.2 & 3.7 & 12.4 & 1.6 & 8.5 & 15.8 \\
\hline Vietnam & 0.9 & 4.6 & 11.0 & 0.6 & 4.2 & 10.6 & 1.5 & 5.9 & 11.3 & 1.2 & 6.5 & 13.5 \\
\hline Rest of ASEAN & 0.3 & 2.0 & 5.5 & 0.0 & -0.3 & 0.8 & -0.1 & -0.5 & 0.7 & 0.3 & 1.9 & 5.1 \\
\hline Japan & 14.5 & 58.3 & 103.0 & 4.8 & 42.0 & 109.6 & 7.0 & 46.6 & 112.7 & 17.0 & 70.5 & 115.9 \\
\hline China & 30.0 & 195.9 & 543.8 & -0.3 & 13.3 & 202.3 & -1.3 & 17.0 & 211.8 & 29.8 & 217.2 & 588.5 \\
\hline Korea & 5.2 & 24.1 & 44.8 & -0.1 & 10.3 & 38.7 & -0.1 & 11.2 & 40.3 & 5.2 & 30.0 & 52.3 \\
\hline Taiwan & -0.9 & 4.2 & 18.4 & 0.0 & 1.6 & 13.5 & 0.0 & 2.1 & 14.4 & -0.9 & 5.0 & 20.3 \\
\hline India & 8.4 & 50.4 & 137.4 & 0.0 & 4.6 & 57.7 & 0.0 & 6.8 & 62.7 & 8.3 & 52.2 & 137.6 \\
\hline Australia & 2.6 & 12.0 & 21.0 & 0.8 & 4.5 & 11.9 & 0.9 & 3.8 & 10.3 & 2.8 & 12.7 & 20.9 \\
\hline New Zealand & 0.3 & 1.5 & 3.0 & 0.2 & 1.3 & 2.8 & 0.2 & 1.2 & 2.7 & 0.3 & 1.6 & 3.2 \\
\hline United States & -3.5 & -11.4 & 20.8 & -0.5 & 15.2 & 66.3 & 9.7 & 55.7 & 120.0 & -4.0 & 3.4 & 66.9 \\
\hline Canada & -0.4 & -0.6 & 6.5 & 1.3 & 8.3 & 18.2 & 2.9 & 9.5 & 17.3 & 0.9 & 7.7 & 19.2 \\
\hline Mexico & -0.1 & -0.3 & 6.7 & 1.2 & 10.5 & 24.9 & 3.0 & 13.4 & 26.1 & 1.2 & 10.3 & 25.1 \\
\hline Chile & -0.1 & -0.2 & 2.3 & 0.3 & 2.3 & 6.4 & 0.5 & 2.7 & 6.5 & 0.2 & 2.1 & 6.4 \\
\hline Peru & 0.0 & 0.0 & 1.3 & 0.3 & 1.6 & 3.8 & 0.4 & 1.6 & 3.7 & 0.3 & 1.6 & 4.1 \\
\hline Russia & -1.1 & -0.4 & 17.5 & -0.3 & -3.0 & 7.0 & -0.7 & -5.4 & 4.4 & -1.3 & -2.4 & 14.0 \\
\hline EU-28 & -2.9 & -22.6 & -78.2 & 0.4 & 0.0 & -40.1 & 0.3 & 1.8 & -38.4 & -2.7 & -22.6 & -75.5 \\
\hline Rest of world & -8.3 & -28.2 & -46.0 & -1.5 & -22.2 & -70.1 & -3.8 & -31.6 & -79.3 & -9.1 & -39.4 & -60.1 \\
\hline
\end{tabular}

Definitions of scenarios:

Scenario 1: RCEP over the period 2019-2028, RCEP + Taiwan from 2024-2033 and FTAAP from 2028-2035. Scenario 2: TPP-11 (TPP sans US) from 2019-2028, TPP-16 from 2024-2033, and FTAAP from 2028-2035. Scenario 3: Same as Scenario 2, except that the United States is assumed to reverse its decision to withdraw from the TPP. Scenario 4: RCEP and TPP-11 over the period 2019-2028, RCEP + Taiwan and TPP-16 from 20242033 and FTAAP from 2028-2035. In all four scenarios, 80\% of FTAAP is assumed to be implemented in 2035. 
Table 4 (continued)

B. Percent changes

\begin{tabular}{|c|c|c|c|c|c|c|c|c|c|c|c|c|}
\hline & \multicolumn{3}{|c|}{$\begin{array}{l}\text { Scenario } 1 \\
\text { (Asian track) }\end{array}$} & \multicolumn{3}{|c|}{$\begin{array}{c}\text { Scenario } 2 \\
(\text { Trans-Pacific track } 1)\end{array}$} & \multicolumn{3}{|c|}{$\begin{array}{c}\text { Scenario } 3 \\
\text { (Trans-Pacific track 2) }\end{array}$} & \multicolumn{3}{|c|}{$\begin{array}{c}\text { Scenario } 4 \\
\text { (Two tracks) }\end{array}$} \\
\hline & 2022 & 2028 & 2034 & 2022 & 2028 & 2034 & 2022 & 2028 & 2034 & 2022 & 2028 & 2034 \\
\hline Singapore & 0.5 & 2.3 & 3.7 & 0.2 & 1.6 & 3.7 & 0.2 & 1.6 & 3.7 & 0.6 & 2.6 & 3.9 \\
\hline Brunei & 0.2 & 0.8 & 1.6 & 0.1 & 0.5 & 0.9 & 0.1 & 0.3 & 0.7 & 0.2 & 0.8 & 1.6 \\
\hline Indonesia & 0.3 & 1.3 & 2.4 & 0.0 & 0.4 & 1.5 & 0.0 & 0.3 & 1.5 & 0.3 & 1.5 & 2.7 \\
\hline Malaysia & 0.3 & 1.4 & 2.8 & 0.2 & 1.2 & 2.7 & 0.3 & 1.2 & 2.7 & 0.3 & 1.7 & 3.0 \\
\hline Philippines & 0.3 & 1.4 & 3.1 & 0.0 & 0.5 & 2.2 & 0.0 & 0.4 & 2.2 & 0.3 & 1.6 & 3.6 \\
\hline Thailand & 0.5 & 2.0 & 3.7 & 0.0 & 1.1 & 3.3 & -0.1 & 1.1 & 3.4 & 0.5 & 2.5 & 4.3 \\
\hline Vietnam & 0.5 & 1.8 & 3.2 & 0.3 & 1.7 & 3.1 & 0.8 & 2.4 & 3.3 & 0.6 & 2.6 & 3.9 \\
\hline Rest of ASEAN & 0.2 & 1.0 & 1.9 & 0.0 & -0.2 & 0.3 & -0.1 & -0.3 & 0.2 & 0.2 & 1.0 & 1.7 \\
\hline Japan & 0.3 & 1.0 & 1.7 & 0.1 & 0.7 & 1.8 & 0.1 & 0.8 & 1.8 & 0.3 & 1.2 & 1.9 \\
\hline China & 0.3 & 1.2 & 2.4 & 0.0 & 0.1 & 0.9 & 0.0 & 0.1 & 0.9 & 0.3 & 1.3 & 2.6 \\
\hline Korea & 0.4 & 1.8 & 3.1 & 0.0 & 0.8 & 2.7 & 0.0 & 0.8 & 2.8 & 0.4 & 2.3 & 3.6 \\
\hline Taiwan & -0.2 & 0.8 & 3.0 & 0.0 & 0.3 & 2.2 & 0.0 & 0.4 & 2.3 & -0.2 & 0.9 & 3.2 \\
\hline India & 0.3 & 1.4 & 2.8 & 0.0 & 0.1 & 1.2 & 0.0 & 0.2 & 1.3 & 0.3 & 1.5 & 2.8 \\
\hline Australia & 0.2 & 0.7 & 1.1 & 0.1 & 0.3 & 0.6 & 0.1 & 0.2 & 0.5 & 0.2 & 0.7 & 1.1 \\
\hline New Zealand & 0.2 & 0.9 & 1.7 & 0.2 & 0.8 & 1.6 & 0.1 & 0.7 & 1.6 & 0.2 & 1.0 & 1.8 \\
\hline United States & 0.0 & -0.1 & 0.1 & 0.0 & 0.1 & 0.4 & 0.1 & 0.3 & 0.7 & 0.0 & 0.0 & 0.4 \\
\hline Canada & 0.0 & 0.0 & 0.3 & 0.1 & 0.4 & 0.8 & 0.2 & 0.5 & 0.8 & 0.0 & 0.4 & 0.8 \\
\hline Mexico & 0.0 & 0.0 & 0.5 & 0.1 & 0.9 & 2.0 & 0.3 & 1.2 & 2.1 & 0.1 & 0.9 & 2.0 \\
\hline Chile & 0.0 & -0.1 & 0.7 & 0.1 & 0.8 & 1.9 & 0.2 & 1.0 & 2.0 & 0.1 & 0.7 & 1.9 \\
\hline Peru & 0.0 & 0.0 & 0.5 & 0.1 & 0.7 & 1.4 & 0.2 & 0.7 & 1.4 & 0.1 & 0.7 & 1.5 \\
\hline Russia & -0.1 & 0.0 & 0.6 & 0.0 & -0.1 & 0.2 & 0.0 & -0.2 & 0.1 & -0.1 & -0.1 & 0.4 \\
\hline EU-28 & 0.0 & -0.1 & -0.4 & 0.0 & 0.0 & -0.2 & 0.0 & 0.0 & -0.2 & 0.0 & -0.1 & -0.4 \\
\hline Rest of world & -0.1 & -0.2 & -0.3 & 0.0 & -0.2 & -0.4 & 0.0 & -0.2 & -0.5 & -0.1 & -0.3 & -0.3 \\
\hline
\end{tabular}

Source: Model simulations. 
welfare gains for these countries in the same year are respectively $3.7 \%$ and $3.2 \% .{ }^{7}$ The economic welfare of several nonmember countries/regions decrease slightly - e.g. contraction of $0.1 \%$ for the United States, Chile, Russia, EU-28 and the rest of the world in 2022 or 2028 and reductions of $0.1-0.4 \%$ for EU-28 and the rest of the world in 2028-34.

In Scenario 2, economic welfare of the TPP-11 countries likewise increases during 2022-2034 and that of the prospective FTAAP members increases in 2034. The percent changes in welfare of the ASEAN countries in Scenario 2 are less than or equal to those in Scenario 1. This result mainly stems from two reasons. First, while all 10 ASEAN countries are RCEP members, only Singapore, Brunei, Malaysia and Vietnam are TPP-11 members. Second, for the four ASEAN economies that are TPP members, their trade with the RCEP members excluding ASEAN (i.e. Australia, China, India, Japan, Korea and New Zealand) is greater than their trade with non-ASEAN TPP-11 countries (i.e. Australia, Canada, Chile, Japan, Mexico, New Zealand and Peru). Since China is the largest trading partner for all ASEAN countries, its exclusion from the TPP and TPP sans US causes smaller welfare gains for Brunei, Malaysia and Vietnam in all years and for Singapore until 2033 in Scenarios 2 and 3 compared with Scenario 1. In 2034 and 2035, the welfare gains for Singapore are roughly equal among the three scenarios largely because the FTAAP will be mostly implemented by those years.

Scenario 3 is included mainly to compare the welfare results of the United States under the first two scenarios with this hypothetical scenario. Not surprisingly, U.S. welfare changes are considerably greater in Scenario 3 that assumes its participation at the start of the TPP than in Scenario 2, which assumes that its participation is delayed by five years. The difference in welfare gains for the U.S. between the two scenarios is projected to be $\$ 53.7$ billion in constant dollars or 0.3 percentage point in 2034. Furthermore, if the RCEP is implemented but TPP sans US is not, the difference in welfare changes for the U.S. is estimated to become $\$ 99.2$ billion or 0.6 percentage point in 2034. In Scenario 1, the U.S. welfare changes relative to the baseline are projected to be negative until 2031 before they become positive in 2032, which is the fifth year of implementation of the FTAAP. Among the ASEAN countries, Vietnam's welfare gains are noticeably larger under Scenario 3.

\footnotetext{
7 The real GDP results are available upon request from the corresponding author.
} 
This is probably because the ratio of Vietnam's exports to the U.S. to its total exports $(16.9 \%)$ is large and significantly greater than the ratio for the 10 ASEAN countries as a whole $(8.9 \%)$.

Welfare gains of the RCEP and TPP-11 countries under Scenario 4 are less than the sum of the gains under Scenarios 1 and 2 because of the considerable overlapping memberships. Specifically, seven countries (Singapore, Brunei, Malaysia, Vietnam, Japan, Australia and New Zealand) are members of the RCEP, TPP-11 and FTAAP. Another reason why the four scenarios yield relatively similar results in 2034 are because FTAAP is assumed to be implemented from 2028 in all scenarios, gradually reducing the differences in the impacts among the Asian track, Trans-Pacific track and two tracks. Nevertheless, the welfare effects are quite different between the scenarios in 2034 for some countries, such as China and the United States. ${ }^{8}$

\subsection{Sectoral Output Adjustments}

Structural adjustments and resource reallocations result from trade accords. The FTA groupings and differences in the initial tariff rates across sectors and member countries play a critical role in determining the direction of the adjustments in sectoral output. Other factors that affect the magnitude and direction of output adjustments for each product category include the import-demand ratio, the export-output ratio, the share of each imported intermediate input in total costs, and the elasticity of substitution between domestic and imported products (Itakura and Lee, 2012).

Tables 5.1-5.4 present the sectoral output adjustments for Singapore, Indonesia, Malaysia, the Philippines, Thailand and Vietnam under Scenarios 1-4, expressed in percent changes relative to the baseline in 2030. In Singapore, output of most of agricultural and manufacturing products falls with the exception of petroleum products, chemical products and nonferrous metals under both scenarios. However, increases in output of tertiary

\footnotetext{
${ }^{8}$ When the order of sequencing remains the same, but the starting year of a particular MRTA (e.g. FTAAP) changes, then it affects the magnitudes of changes in economic welfare and sectoral output. The earlier the starting year of the implementation, the greater the absolute and percentage changes in welfare and sectoral output in the final year. If the member countries are ranked by percent welfare gains, the ranking order is almost always maintained when the starting year of an MRTA is changed.
} 
sectors more than offset reductions in output of primary and secondary sectors, since services account for about three-quarters of GDP in Singapore.

Output adjustments in agricultural and service sectors in the ASEAN-4 countries are relatively similar. In all four scenarios, output of some agricultural products decreases, such as other grains and sugar in all four countries, meats in Malaysia and the Philippines,

Table 5.1. Sectoral output adjustments in selected ASEAN countries under Scenario 1:

Percent changes relative to the baseline in 2030

\begin{tabular}{|c|c|c|c|c|c|c|}
\hline Sector & SGP & IDN & MYS & PHL & THA & VNM \\
\hline Rice & -2.1 & 0.1 & -0.4 & -0.3 & 0.0 & -0.1 \\
\hline Other grains & 0.1 & -1.3 & -3.6 & -1.4 & -2.4 & -1.1 \\
\hline Sugar & -4.9 & -1.5 & -0.6 & -0.7 & -0.9 & 0.5 \\
\hline Other crops & -4.4 & 0.1 & 0.4 & 0.7 & -0.3 & -0.7 \\
\hline Livestock & -1.0 & 1.0 & 1.2 & 1.0 & 1.2 & 1.4 \\
\hline Meats & -10.4 & 0.4 & -3.6 & -4.8 & 1.5 & -7.1 \\
\hline Dairy products & -7.1 & -1.5 & -0.2 & -1.5 & 0.5 & -0.2 \\
\hline Other food products & 3.5 & 1.6 & 1.9 & 0.0 & 1.3 & -0.8 \\
\hline Fossil fuels & -2.2 & 0.3 & 0.3 & 0.1 & -2.2 & 0.4 \\
\hline Natural resources & 0.6 & 1.4 & 1.6 & 0.7 & 2.3 & 1.0 \\
\hline Textiles & -9.2 & -3.1 & -1.1 & -0.5 & -1.2 & 4.9 \\
\hline Apparel & -4.2 & -4.4 & 0.1 & 1.7 & 0.0 & 12.3 \\
\hline Petroleum products & 4.8 & -0.6 & 1.7 & 0.6 & 2.5 & 0.5 \\
\hline Chemical products & 2.2 & -3.5 & 2.2 & -1.3 & 2.9 & 0.7 \\
\hline Steel & -11.5 & -0.1 & -1.9 & -2.3 & 1.4 & 5.1 \\
\hline Nonferrous metal & 23.7 & -5.4 & 21.8 & -2.5 & -0.1 & 10.9 \\
\hline Metal products & -6.6 & 4.6 & 5.3 & 1.1 & 5.5 & 2.2 \\
\hline Machinery & -6.4 & -4.2 & 1.6 & 1.1 & 6.0 & 6.1 \\
\hline Electronic equipment & -5.4 & 0.7 & 1.5 & 1.7 & 6.4 & 10.4 \\
\hline Motor vehicles & -5.8 & -2.3 & 2.7 & 4.2 & 7.2 & 3.0 \\
\hline Other transport equip. & -6.6 & -2.6 & 4.9 & -5.4 & 5.6 & 3.6 \\
\hline Other manufactures & -2.8 & 2.1 & 0.9 & 1.3 & 0.8 & 0.7 \\
\hline Construction and utilities & 4.6 & 6.3 & 3.8 & 4.4 & 10.8 & 10.5 \\
\hline Trade & 2.2 & 2.1 & 3.3 & 1.6 & 4.3 & 3.4 \\
\hline Transport & 0.3 & 0.9 & 2.4 & 2.8 & 3.4 & 8.7 \\
\hline Communication & 0.1 & -0.5 & 1.0 & 0.8 & 1.8 & 0.7 \\
\hline Financial services & 0.2 & 1.1 & 0.8 & 1.6 & 2.6 & -2.7 \\
\hline Other private services & 1.9 & 1.4 & 0.1 & 0.9 & 0.5 & 1.6 \\
\hline Government services & 1.9 & 0.2 & 0.2 & 0.7 & -0.2 & 0.1 \\
\hline
\end{tabular}

Source: Model simulations. 
Table 5.2. Sectoral output adjustments in selected ASEAN countries under Scenario 2:

Percent changes relative to the baseline in 2030

\begin{tabular}{|c|c|c|c|c|c|c|}
\hline Sector & SGP & IDN & MYS & PHL & THA & VNM \\
\hline Rice & -1.7 & 0.1 & -0.2 & -0.1 & -0.5 & -1.1 \\
\hline Other grains & -0.5 & -1.3 & -3.7 & -1.3 & -3.0 & -0.8 \\
\hline Sugar & -4.1 & -1.2 & -0.6 & -0.7 & -2.3 & -0.3 \\
\hline Other crops & -4.3 & -0.3 & 0.1 & 0.3 & -0.3 & -1.2 \\
\hline Livestock & -0.8 & 0.3 & 1.8 & 0.2 & 0.5 & 1.6 \\
\hline Meats & -8.9 & -0.2 & -4.0 & -4.3 & 0.2 & -6.5 \\
\hline Dairy products & -5.7 & -1.4 & -0.1 & -2.8 & -0.8 & -2.6 \\
\hline Other food products & 2.5 & -0.4 & 0.8 & -0.5 & 0.0 & -1.9 \\
\hline Fossil fuels & -1.9 & -0.1 & 0.3 & -0.2 & -1.7 & 0.2 \\
\hline Natural resources & 0.6 & 0.5 & 1.2 & 0.1 & 1.2 & 0.7 \\
\hline Textiles & -4.0 & 0.6 & 6.1 & 8.9 & 0.4 & 12.5 \\
\hline Apparel & -4.1 & 4.4 & 17.7 & 13.7 & 2.4 & 23.5 \\
\hline Petroleum products & 4.2 & -0.7 & 2.3 & 0.3 & 1.0 & 1.0 \\
\hline Chemical products & 3.1 & -2.9 & 3.0 & -1.4 & -0.3 & -1.8 \\
\hline Steel & -9.4 & -0.8 & -1.1 & -2.9 & -2.0 & -0.1 \\
\hline Nonferrous metal & 13.5 & -3.9 & 10.3 & -1.9 & -1.4 & 1.1 \\
\hline Metal products & -5.0 & 2.6 & 5.1 & 0.1 & 3.1 & -1.8 \\
\hline Machinery & -3.5 & -2.9 & 3.1 & 0.3 & 1.8 & -0.8 \\
\hline Electronic equipment & -3.4 & 0.1 & 1.4 & -1.5 & 0.2 & 0.2 \\
\hline Motor vehicles & -4.1 & -1.7 & 2.3 & 2.3 & 3.4 & 2.4 \\
\hline Other transport equip. & -5.5 & -1.8 & 4.4 & -2.9 & 3.3 & 2.9 \\
\hline Other manufactures & -2.2 & 1.1 & 1.3 & 0.3 & 0.2 & 1.5 \\
\hline Construction and utilities & 3.6 & 3.6 & 3.7 & 2.7 & 7.0 & 11.5 \\
\hline Trade & 0.6 & 0.9 & 3.2 & 0.6 & 2.0 & 3.1 \\
\hline Transport & -0.9 & 0.2 & 2.1 & 1.4 & 1.7 & 8.5 \\
\hline Communication & -0.5 & -0.9 & 0.8 & 0.0 & 0.2 & 0.1 \\
\hline Financial services & -0.5 & 0.2 & 0.6 & 0.5 & 0.9 & -4.7 \\
\hline Other private services & 1.0 & 0.2 & -0.1 & -0.1 & -0.9 & 0.8 \\
\hline Government services & 1.4 & -0.3 & -0.1 & 0.0 & -0.2 & -0.8 \\
\hline
\end{tabular}

Source: Model simulations.

and dairy products in Indonesia and the Philippines. Somewhat surprisingly, output of most services sectors are projected to expand in all four countries, particularly under Scenarios 1 and 4 . This is largely caused by a $20 \%$ cut in relatively high NTBs on services trade. Reductions in the costs of intermediate services, particularly trade, transport and communication services, facilitates trade in goods and services. 
Vietnam is projected to undergo greater output changes than the ASEAN-4 economies. It will benefit from increases in output of manufacturing and services sectors except financial and government services. In both absolute and percentage changes, increases in unskilled-labor-intensive textiles and apparel are particularly large. It is noteworthy that Vietnam will enjoy greater percentage increase in output of electronic equipment than

Table 5.3. Sectoral output adjustments in selected ASEAN countries under Scenario 3:

Percent changes relative to the baseline in 2030

\begin{tabular}{lrrrrrr}
\hline Sector & SGP & IDN & MYS & PHL & THA & VNM \\
\hline Rice & -1.6 & 0.2 & 0.0 & 0.0 & -0.4 & -1.4 \\
Other grains & -0.4 & -1.3 & -4.3 & -1.3 & -3.2 & -0.5 \\
Sugar & -4.0 & -1.2 & -0.6 & -0.7 & -2.4 & -0.2 \\
Other crops & -4.2 & -0.3 & 0.0 & 0.3 & -0.4 & -1.6 \\
Livestock & -0.8 & 0.3 & 2.1 & 0.2 & 0.4 & 1.9 \\
Meats & -9.0 & -0.3 & -4.5 & -4.2 & 0.1 & -7.8 \\
Dairy products & -5.9 & -1.4 & -0.2 & -3.1 & -0.9 & -3.0 \\
Other food products & 2.2 & -0.4 & 1.0 & -0.5 & -0.2 & -2.1 \\
Fossil fuels & -2.1 & -0.1 & 0.2 & -0.2 & -1.8 & 0.1 \\
Natural resources & 0.6 & 0.4 & 1.3 & 0.1 & 1.2 & 1.1 \\
Textiles & -2.6 & 0.8 & 8.5 & 8.4 & 0.4 & 22.8 \\
Apparel & -4.0 & 4.2 & 25.5 & 12.5 & 1.9 & 39.3 \\
Petroleum products & 4.3 & -0.8 & 2.4 & 0.3 & 1.1 & 1.6 \\
Chemical products & 3.3 & -2.9 & 3.6 & -1.5 & -0.2 & -0.8 \\
Steel & -9.6 & -0.9 & -0.9 & -2.9 & -2.1 & 0.0 \\
Nonferrous metal & 13.0 & -3.6 & 10.6 & -1.8 & -1.6 & 2.3 \\
Metal products & -5.1 & 2.4 & 5.3 & 0.1 & 3.1 & -1.8 \\
Machinery & -3.6 & -2.6 & 3.7 & 0.4 & 1.8 & -0.8 \\
Electronic equipment & -3.3 & 0.4 & 1.8 & -1.5 & 0.1 & 0.2 \\
Motor vehicles & -4.3 & -1.7 & 2.4 & 2.2 & 3.2 & 3.2 \\
Other transport equip. & -5.5 & -1.7 & 4.9 & -2.9 & 3.4 & 3.7 \\
Other manufactures & -2.5 & 1.0 & 1.2 & 0.3 & 0.3 & 3.1 \\
Construction and utilities & 3.2 & 3.3 & 4.0 & 2.6 & 7.1 & 14.1 \\
Trade & 0.6 & 0.8 & 3.4 & 0.6 & 2.1 & 4.3 \\
Transport & -0.8 & 0.2 & 2.3 & 1.4 & 1.8 & 10.4 \\
Communication & -0.4 & -0.9 & 0.9 & 0.0 & 0.2 & 1.5 \\
Financial services & -0.4 & 0.1 & 0.8 & 0.5 & 0.9 & -3.7 \\
Other private services & 0.8 & 0.2 & 0.0 & -0.1 & -0.9 & 1.8 \\
Government services & 1.3 & -0.3 & -0.1 & 0.0 & -0.2 & -0.6 \\
\hline & & & & & & \\
\hline
\end{tabular}

Source: Model simulations. 
Table 5.4. Sectoral output adjustments in selected ASEAN countries under Scenario 4:

Percent changes relative to the baseline in 2030

\begin{tabular}{lrrrrrr}
\hline Sector & SGP & IDN & MYS & PHL & THA & VNM \\
\hline Rice & -2.1 & 0.2 & -0.1 & -0.2 & -0.1 & -1.0 \\
Other grains & 0.1 & -1.6 & -4.8 & -1.8 & -3.5 & -1.3 \\
Sugar & -5.0 & -1.6 & -0.7 & -0.8 & -1.5 & 0.0 \\
Other crops & -4.5 & 0.0 & 0.2 & 0.7 & -0.4 & -1.4 \\
Livestock & -0.9 & 1.0 & 1.7 & 0.9 & 1.2 & 1.8 \\
Meats & -10.7 & 0.3 & -5.2 & -6.4 & 1.3 & -10.5 \\
Dairy products & -7.2 & -1.6 & -0.4 & -2.4 & 0.3 & -2.2 \\
Other food products & 2.8 & 1.3 & 1.9 & -0.2 & 0.8 & -2.3 \\
Fossil fuels & -2.5 & 0.2 & 0.2 & 0.0 & -2.6 & 0.2 \\
Natural resources & 0.6 & 1.4 & 1.6 & 0.7 & 2.4 & 1.0 \\
Textiles & -7.0 & -0.5 & 2.9 & 8.4 & 1.6 & 14.9 \\
Apparel & -4.1 & 2.2 & 16.8 & 14.4 & 4.0 & 30.1 \\
Petroleum products & 5.0 & -0.5 & 1.9 & 0.9 & 2.7 & 0.9 \\
Chemical products & 2.5 & -3.7 & 2.7 & -1.2 & 2.8 & -0.7 \\
Steel & -11.6 & -0.2 & -2.0 & -3.2 & 0.9 & 2.3 \\
Nonferrous metal & 23.4 & -5.7 & 21.9 & -2.6 & -0.1 & 8.6 \\
Metal products & -6.7 & 4.8 & 5.4 & 0.8 & 6.0 & -1.2 \\
Machinery & -6.6 & -4.3 & 2.3 & 0.8 & 5.9 & 1.8 \\
Electronic equipment & -5.3 & 0.9 & 1.5 & 0.6 & 5.9 & 5.5 \\
Motor vehicles & -6.0 & -2.2 & 2.8 & 4.5 & 7.9 & 3.2 \\
Other transport equip. & -6.7 & -2.7 & 4.8 & -6.3 & 5.5 & 2.4 \\
Other manufactures & -3.0 & 2.2 & 0.8 & 1.2 & 0.9 & 1.0 \\
Construction and utilities & 4.3 & 6.5 & 4.1 & 5.1 & 12.1 & 14.6 \\
Trade & 2.2 & 2.2 & 3.6 & 1.7 & 4.7 & 4.4 \\
Transport & 0.4 & 0.9 & 2.6 & 3.0 & 3.7 & 11.4 \\
Communication & 0.2 & -0.6 & 1.1 & 0.8 & 1.9 & 1.0 \\
Financial services & 0.2 & 1.1 & 0.9 & 1.7 & 2.9 & -4.0 \\
Other private services & 1.8 & 1.3 & 0.1 & 0.8 & 0.4 & 1.8 \\
Government services & 1.8 & 0.1 & 0.1 & 0.6 & -0.2 & -0.4 \\
\hline & & & & & & \\
\hline
\end{tabular}

Source: Model simulations.

ASEAN-4 through global supply chains in the region. ${ }^{9}$ Under Scenarios 2 and 3, however, output of electronic equipment will be nearly unchanged, mainly because its exports to China will become significantly smaller.

\footnotetext{
9 This result is consistent with Petri et al.'s (2015) sectoral results, which show that Vietnam's value added in electrical equipment under TPP-12, RCEP and FTAAP will be respectively $11.1 \%, 6.3 \%$ and $8.3 \%$ greater than their baseline values in 2025 .
} 
Under Scenario 1, percent changes in output of apparel will be positive but small (Philippines), negative (Indonesia), or virtually unchanged (Malaysia and Thailand). This is because ASEAN-4's apparel exporters face strong competition from Chinese exporters. Output of electronic equipment and metal products increases in all four countries. In particular, electronic equipment is projected to become a major export product of the ASEAN-4 countries, and the elimination of the remaining tariffs will further increase exports and output of this product through production networks across East and Southeast Asian economies. Other sectors with notable expansion include machinery, motor vehicles and other transport equipment in Thailand.

Under Scenario 2, ASEAN-4's output of apparel is projected to expand significantly, particularly in Malaysia and the Philippines. Since China is not a member of TPP sans US or an enlarged TPP, ASEAN-4's exporters do not face much competition from Chinese manufacturers until the FTAAP is largely implemented in the mid-2030s. By contrast, its percent changes in output of electronic equipment relative to the baseline are either small or negative (Philippines). Again, China is the main factor, as ASEAN's growth in this industry will continue to be greatly driven by rapid growth in exports to China. Thus, the exclusion of China from MRTAs until 2028 will reduce projected output of electronic equipment under the second scenario relative to the first one.

The inclusion of the United States in the TPP from the beginning of its implementation (Scenario 3) has small effects on sectoral output of ASEAN countries. In Malaysia and Vietnam it has positive effects on output of several manufacturing sectors, particularly textiles and apparel. In Singapore, another original members of the TPP, changes in sectoral output under Scenario 3 are similar to those under Scenario 2. This is because Singapore has already implemented a bilateral FTA with the United States.

In Scenario 4, ASEAN-4 economies and Vietnam benefit from expansion of several manufacturing and services sectors, particularly in apparel, electronic equipment, construction and utilities, trade, and transport. Among the ASEAN countries Vietnam would experience the greatest sectoral output adjustments. However, the sector that is predicted to suffer from the largest contraction (meats) is a very small sector, whereas the sectors that are projected to expand by more than $10 \%$ (textiles, apparel, construction and 
utilities, transport) are large sectors. Nevertheless, retraining displaced workers and providing job search assistance would be warranted to reduce the negative impact of implementing MRTAs.

\section{Conclusion}

In this paper, we have used the dynamic GTAP model to investigate how MRTAs might affect economic welfare and sectoral output adjustments in ASEAN countries. Under the first scenario in which the proposed RCEP agreement is implemented over the 2019-2028 period, followed by RCEP + Taiwan from 2024-2033 and the FTAAP from 2028-2035, the welfare gains for the ASEAN countries in 2034 range from $1.6 \%$ to $3.7 \%$. In the second scenario, TPP sans US is implemented over the 2019-2028 period, followed by an extension of the TPP membership to Korea, Indonesia, the Philippines, Thailand and the United States and an implementation of the enlarged TPP during 2024-2033. It is then followed by an implementation of the FTAAP during 2028-2035. The percentage changes in economic welfare of the ASEAN countries in Scenario 2 are less than or equal to those in Scenario 1. The third scenario is included to compare the welfare effects of the TPP with and without U.S. participation at the start of the TPP. The U.S. participation from the beginning of the TPP would substantially increase Vietnam's welfare gains, while it only marginally affects other ASEAN countries' welfare changes. In the final scenario, the Asian track (Scenario 1) and the Trans-Pacific track (Scenario 2) are assumed to develop at the same time. Welfare gains of the RCEP and TPP-11 countries under this scenario are found to be less than the sum of the gains under the first two scenarios. This is caused by substantial overlapping memberships and the assumption that the FTAAP would be implemented from 2028 in all scenarios.

Sectoral output adjustments in ASEAN countries are similar among the four scenarios. In Singapore, increases in output of services sectors more than offset reductions in output of agricultural and manufacturing sectors. In the ASEAN-4 countries and Vietnam, output of a wide range of manufacturing products and services increases. Reductions in costs of intermediate inputs, including intermediate services, through eliminations of tariffs and reductions in NTBs appear to be an important factor in boosting output of many 
manufacturing and services sectors. In particular, output of electronic equipment is projected to increase significantly through global value chains in East and Southeast Asia.

\section{References}

Aguiar, A., Narayanan, B., and McDougall, R. (2016). An overview of the GTAP 9 data base. Journal of Global Economic Analysis, 1(1), 181-208.

Ahn, J., Dabla-Norris, E., Duval, R., Hu, B., and Njie, L. (2016). Reassessing the productivity gains from trade liberalization. IMF Working Paper WP/16/77. Washington, DC: International Monetary Fund.

Amiti, M., and Khandelwal, A. (2013). Import competition and quality upgrading. Review of Economics and Statistics, 95(2), 476-490.

Armington, P. (1969). A theory of demand for products distinguished by place of production. IMF Staff Papers, 16, 159-178.

Balistreri, E. J., and Markusen, J. R. (2009). Sub-national differentiation and the role of the firm in optimal international pricing. Economic Modelling, 26, 47-62.

Brown, D. K. (1987). Tariffs, the terms of trade, and national product differentiation. Journal of Policy Modeling, 9, 503-526.

Brown, D. K., Kiyota, K., and Stern, R. M. (2010). Computational analysis of the menu of U.S.-Japan trade policies. RSIE Discussion Paper No. 611, Ford School of Public Policy, University of Michigan.

Chen, N., Imbs, J., and Scott, A. (2009). The dynamics of trade and competition. Journal of International Economics, 77, 50-62.

Cheong, I., and Tongzon, J. (2013). Comparing the economic impact of the Trans-Pacific Partnership and the Regional Comprehensive Economic Partnership. Asian Economic Papers, 12(2), 144-64.

Halpern, L., Koren, M., and Szeidl, A. (2015). Imported inputs and productivity. American Economic Review, 105(12), 3660-3703.

Hertel, T.W. (Ed.) (1997). Global Trade Analysis: Modeling and Applications. Cambridge: Cambridge University Press.

Hummels, D. L., and Schaur, G. (2013). Time as a trade barrier. American Economic Review, 103(7), 2935-59. 
Ianchovichina, E., and McDougall, R. (2012). Theoretical structure of dynamic GTAP. In: E. Ianchovichina and T. L, Walmsley (Eds.), Dynamic Modeling and Applications for Global Economic Analysis. Cambridge: Cambridge University Press.

International Monetary Fund (2016). World Economic Outlook Database, October. Washington, DC: International Monetary Fund.

Itakura, K. and Lee, H. (2012). Welfare changes and sectoral adjustments of Asia-Pacific countries under alternative sequencings of free trade agreements. Global Journal of Economics, 1(2), 1250012.

Kawai, M., and Wignaraja, G. (2009). Multilateralizing regional trade arrangements in Asia. In: R. Baldwin and P. Low (Eds.), Multilateralizing Regionalism: Challenges for the Global Trading System. Cambridge: Cambridge University Press.

Kawasaki, K. (2015). The relative significance of EPAs in Asia-Pacific. Journal of Asian Economics, 39, 19-30.

Lee, H., Owen, R. F., and van der Mensbrugghe, D. (2009). Regional integration in Asia and its effects on the EU and North America. Journal of Asian Economics, 20, 240-254.

Li, C., and Whalley, J. (2014). China and the Trans-Pacific Partnership: A numerical simulation assessment of the effects involved. World Economy, 37(2), 169-192.

Lileeva, A. (2008). Trade liberalization and productivity dynamics: Evidence from Canada. Canadian Journal of Economics, 41(2), 360-390.

Minor, P. (2013). Time as a barrier to trade: A GTAP database of ad valorem trade time costs. ImpactEcon, Second Edition.

Petri, P. A., and Plummer, M. G. (2016). The economic effects of the TPP: New estimates. In: C. Cimino-Isaacs and J. J. Schott, eds., Trans-Pacific Partnership: An Assessment. Washington, DC: Peterson Institute for International Economics.

Petri, P. A., Plummer, M. G., and Zhai, F. (2012). Trans-Pacific Partnership and AsiaPacific Integration: A Quantitative Assessment. Washington, DC: Peterson Institute of International Economics.

Petri, P. A., Plummer, M. G., and Zhai, F. (2014). The TPP, China and the FTAAP: The case for convergence. In: G. Tang and P. A. Petri, eds., New Directions in Asia-Pacific Economic Integration. Honolulu: East-West Center.

Petri, P. A., Plummer, M. G., and Zhai, F. (2015). Sectoral results for TPP, RCEP and FTAAP, 15 March 2015. Asia-Pacific Trade website. http://asiapacifictrade.org/. Accessed July 2014 and May 2015. 
Schott, J. J. (2016). TPP could go forward without the United States. November 15. Washington, DC: Peterson Institute for International Economics. https://piie.com/blogs/ trade-investment-policy-watch/tpp-could-go-forward-without-united-states. Accessed November 2016.

Solís, M. (2016). The TPP is dead, long live the TPP. November 11. Brookings Institution. https://www.brookings.edu/blog/order-from-chaos/2016/11/11/the-tpp-is-dead-longlive-the-tpp/. Accessed November 2016.

Trefler, D. (2004). The long and short of the Canada-U.S. Free Trade Agreement. American Economic Review, 94(4), 870-895.

United Nations (2015). World Population Prospects: The 2015 Revision. Department of Economics and Social Affairs, Population Division. New York: United Nations.

United Nations Conference on Trade and Development (UNCTAD) (2017). Bilateral FDI statistics. http://unctad.org/en/Pages/DIAE/FDI\%20Statistics/FDI-StatisticsBilateral.aspx. Accessed January 2017.

Wang, Z., Mohan, S., and Rosen, D. (2009). Methodology for estimating services trade barriers. Rhodium Group and Peterson Institute for International Economics.

World Bank (2016). Potential macroeconomic implications of the Trans-Pacific Partnership. In: Global Economic Prospects: Spillovers amid Weak Growth. Washington, DC: World Bank, January. 